\title{
The preoperative scheduling system as a secondary tool for hospital management: suggestions for adjustments proposed by a university ophthalmology unit
}

\author{
Fila cirúrgica digital como instrumento auxiliar de gestão \\ hospitalar: Sugestões de adequações propostas por um serviço \\ universitário de oftalmologia
}

Nadyr Antonia Damasceno', Marcelo Palis Ventura², Guilherme Herzog Neto², Eduardo F. Damasceno

\begin{abstract}
Objective: To evaluate the incidence of a software program package at Brazilian public eye care institutions through an online survey. The package is made up of the institutions' websites, electronic medical records, regulatory assistance control system and the preoperative scheduling system. The aim is to analyze if this type of software facilitates the provisioning of eye care services, the patients' surgical procedure agenda, and access to information about the patients. Methods: Public health care institutions with eye care services were divided into multidisciplinary university hospitals, multidisciplinary health system hospitals, single discipline hospitals (only ophthalmology) and eye banks (when linked to public health care). Two kinds of data were evaluated on the Internet: I) ophthalmology institutions and the correlation with the presence of the software program, II) ophthalmology institutions and the correlation with the software source. A statistical analysis was performed using chi-square and Fisher's exact test. Significance levels were estimated at 0.05. Results: 48 public institutions were evaluated at 24 universities, 15 health care institutions, 3 single discipline hospital institutions (ophthalmology only), and 6 institutions specifically referred to as eye banks. In this survey, the digital preoperative scheduling system was only found in 10.4\% of the institutions. After the statistical analysis, the eye bank was the only relevant institution that was significantly related to the presence of the digital preoperative scheduling system. Conclusion: Preoperative scheduling systems are expected to provide a good support tool for administrative management. However, this type of instrument as a software program is rarely found in public health care institutions in Brazil.
\end{abstract}

Keywords: Hospital administration/standard; Medical record systems, computerized; Electronic health records; Public health; Health facilities; Brazil

\footnotetext{
${ }^{1}$ Doctoral Program in Medical Science, Faculdade de Medicina, Universidade Federal Fluminense, Niterói, RJ, Brazil.

${ }^{2}$ Faculdade de Medicina, Universidade Federal Fluminense, Niterói, RJ, Brazil.

Research institution: UFF - Faculdade de Medicina.

The authors declare no conflicts of interests.

Received for publication 19/01/2016 - Accepted for publication 03/04/2016.
} 


\section{ReSUMO}

Objetivo: Avaliar, através de busca na internet, quais os serviços públicos com atendimento oftalmológico no Brasil que possuem um pacote digital composto de página da instituição na rede digital, prontuário eletrônico, sistema de regulação de atendimento e fila de espera cirúrgica digital. Enfatizar a presença destes elementos de pesquisa com a condição de funcionamento de fila de espera cirúrgica digital com possibilidade de consulta publica pelo paciente usuário. Métodos: Estudo transversal através de busca na internet de serviços de oftalmologia com este pacote digital completo ou parcial em caráter nacional. Os dados foram pesquisados na internet no período de junho à julho de 2015. As instituições foram divididas em grupos de pesquisa, assim designados: hospitais multidisciplinares universitários, hospitais multidisciplinares assistenciais, hospitais uni-disciplinares assistenciais (somente oftalmologia) e banco de olhos (como entidade de atendimento público). Duas variáveis foram avaliadas: número total e parcial de serviços públicos de oftalmologia que possuem este sistema digital e como foi desenvolvido este pacote digital por cada instituição. Os dados foram avaliados através do teste Qui quadrado e prova exata de Fisher. O nível de significância do estudo foi 0,05. Resultados: Foram encontradas 48 instituições públicas oftalmológicas detentoras deste pacote digital, sendo: 24 universitárias, 15 assistenciais, 3 hospitalares uni-disciplinares (somente oftalmologia), 6 bancos de olhos. Somente 10,4 \% destas instituições apresentaram uma fila de espera cirúrgica digital. Exclusivamente os bancos de olhos obtiveram dados significativos quanto a presença de fila cirúrgica digital, bem como a origem de seu desenvolvimento. Conclusão: Apenas algumas instituições apresentaram um pacote digital completo, porém a fila de espera cirúrgica digital é o componente mais raro destas instituições. Razões desta constatação são explanadas pelo estudo. Embora com pequena representação, em todo território nacional somente dois bancos de olhos apresentaram fila cirúrgica digital com possibilidade de consulta pública.

Descritores: Administração hospitalar/normas; sistemas computadorizados de registros; registros eletrônicos de saúde; saúde pública; instituições de saúde; Brasil

\section{INTRODUCTION}

The national public hospital network of care in ophthalmology is formed by medical services of university hospitals and federal, state and municipal care hospitals. All are made of multi-professional and even multidisciplinary medical entities (various medical specialties). Besides these, there are public institutions formed only by ophthalmology, in particular Banco de Olhos, of unidisciplinary character (only one medical specialty). ${ }^{1-12}$

Many of these entities have digital website, highlighting the academic aspects of a strictu sensu graduation program for university students, or ophthalmological services with emphasis on medical residency in other institutions.

However, many of these ophthalmic public services have problems related to the surgical waiting list. They provide ophthalmic surgical procedures of medium and high complexity, as well as a disparate variety in relation to income and welfare goals. The existence of surgical waiting lists on public hospitals is often a social affliction due to its delay character. This surgical waiting list is a dilemma with multiple requirements in the technical management of the procedure, often impossible to be met due to the precariousness of resources in the public service and the difficulty of monitoring the surgical waiting list by the most needy citizens. ${ }^{6,7}$

As far as reality seems more urgent and dissemination of medical service over the Internet becomes more common, the idea of digital aid and surgical waiting list has been slowly happening. Thus, as a social response, some public institutions with large numbers of surgical care are using the digital surgical line with public consultation. This does not only exist in the specialty of ophthalmology, as well as in others with large surgical activity as in orthopedics, organ transplant specialties and some health care services of the municipalities. However, in the latter case, it ranges from primary, secondary and even tertiary care level. $1,2,6,7$

As this type of digital surgical waiting list is consolidated, it is evident the need for a more organized hospital structure also in its digital character. Accessory structures should be available, such as electronic medical records, integrated service regulation systems at the state government, in addition to the digital page on the Internet. These devices act synergistically together, forming a single digital structure to aid in the management of this type of hospital management. $1,2,5$

Thus, these authors proposed research in ophthalmology in order to assess through internet search which public services to eye care in the country have a digital package comprising the institution's website, electronic medical records, service control system and digital line surgical waiting list. All that to emphasize the existence and the operating condition of the digital surgical waiting list, with emphasis on the possibility of public consultation by the user patient.

\section{Methods}

Cross-sectional study through Internet search that includes ophthalmologic care services of the the public system with a digital page for disclosure. Data was searched on the Internet in the period from June to July 2015.

The study included ophthalmologic medical services subdivided into:

- University - multidisciplinary

- Hospital Care - multidisciplinary

- Hospital Care - unidisciplinary (ophthalmology only)

- Eye Bank - as an entity of public service linked to SUS.

Institutions without a digital page for ophthalmology were excluded.

The variables researched were:

- Main variable

- Presence of a digital page for disclosure in ophthalmological public service.

- Secondary variables

- Presence of electronic medical record for medical care at levels: Integral (both Ambulatory and Administrative like Innerhospital) or Partial (Only Inner-hospital and/or Administrative).

- Participation of a regulatory system for medical care managed by the State at any level (federal, state or municipal).

- Presence digital surgical waiting list.

- With public consultation by interested party

- Without public consultation by interested party

The results were presented in tables. Table I shows the correlation between the primary and secondary variables. Table 
II shows the correlation with the origin of the digital package software, emphasizing its origin either from private companies or of public development. This correlation is built with a complete (with all variables) or partial (only one or two of them) digital package concept.

The statistical analysis was performed using the chi-square test with Fisher's exact test. The significance level to be searched was 0.05 . The statistical software used was SPSS by IBM, 2013 Chicago, USA - version 21.0.

Because it is a study for administrative management of health, the names of each service searched were not specifically disclosed, but the reference sources in which they were evaluated. However, to reduce regional disparities, it was decided to include at least one representative for each state of the union, even in case of establishment of low numbers of consultations.

The sources consulted for making the database were direct queries to Browse to the national websites Google, Yahoo and Microsoft Network (Bing - MSN), the official website of Conselho Brasileiro de Oftalmologia (CBO) and Sociedade Brasileira de Oftalmologia (SBO), portal of UNA-SUS (Universidade Aberta do Sistema Único de Saúde \Arouca platform), websites of Associação Brasileira de Banco de Olhos (ABBO) and Associação Panamericana de Banco de Olhos (APABO).

Private institutions with agreements for public service were not considered, except in cases of service connected to the eye bank as public-private institutions.

\section{RESULTS}

Forty-eight digital pages of the Internet were consulted in this study, representing most public services in ophthalmology care. Only five States in the country were not evaluated due to the absence of hospital department of ophthalmology being disclosed on the Internet.

The 48 institutions included in the study were evaluated as 24 universities, 15 welfare institutions, 3 unidisciplinary hospitals (ophthalmology only), 6 institutions specifically referenced as eye banks. (Table 1 )

The universities have their own characteristics of academic disclosure on the Internet. Some of them (5 universities) have their own digital pages inherent to ophthalmology, as well as participation in the website of Hospital Universitário and/or Faculdade de Medicina or the University.

On the other hand, in many states Hospital de Clínicas Universitário is the main and only institution at tertiary level of public service within the specialty. This often has little disclosure of expertise in the academic web page.

Welfare institutions enhance on the Internet features of their activities, and those of the ophthalmology service internally allocated on the digital pages of the general hospital itself. Sometimes they have additional pages on social networks like Facebook and Twitter. These are used as a contact interface between users' doctors and the patients.

Unidisciplinary institutes only related to ophthalmology are rarer. Overall, they are associated to initially philanthropic or charitable organizations that have become, over time, service providers to SUS (Single Health System) at federal level.

Table 1 shows that the number of care facilities following the digital package (website, full electronic medical record, attendance regulation system and digital surgical waiting list) is still small, especially with regard to electronic medical records and surgical waiting list. The highest percentage of these cases is relevant in the eye banks. This type of data is highlighted as significant in the statistical test (Table 1).

The eye banks form separated service structures. These organizations are newer within the specialty, and can even provide subspecialty services (retina, cataract, eye plastic surgery), besides corneal transplantation. These institutions often act as collectors of the eyeball to be transplanted, being or not effectors of surgical transplant, besides being possible to offer the corneal button to other entities. Some eye banks are directly linked to other state institutions or those accredited to private entities.

Table 1

\section{Service institutions following the digital package at National Character - researched on the Internet during June / July 2015: total data of public services in Ophthalmology}

\begin{tabular}{|c|c|c|c|c|c|c|c|c|c|}
\hline \multirow[t]{2}{*}{ Presence of digital page } & \multirow[t]{2}{*}{$\mathbf{N}$} & \multicolumn{3}{|c|}{ Electronic medical record } & \multicolumn{2}{|c|}{ Regulation system } & \multicolumn{2}{|c|}{ Digital surgical waiting line } & \multirow{2}{*}{$\begin{array}{l}\text { e p Value } \\
\text { Test } \mathrm{X}^{2} \text { Fisher }\end{array}$} \\
\hline & & Integral & Partial & Absent & Present & Absent & Present & Absent & \\
\hline $\begin{array}{l}\text { Multidisciplinary university } \\
\text { institutions }\end{array}$ & 24 & 02 & 17 & 05 & 18 & 06 & 02 & 22 & N.S. \\
\hline $\begin{array}{l}\text { Multidisciplinary assistance } \\
\text { institutions }\end{array}$ & 15 & - & 10 & 05 & 13 & 02 & 01 & 14 & N.S. \\
\hline Eye Bank & 06 & 04 & 02 & - & 06 & - & $02 *$ & $04^{*}$ & 0.05 \\
\hline TOTAL & 48 & 06 & 31 & 11 & 39 & 09 & 05 & 43 & \\
\hline
\end{tabular}

$\mathrm{n}$ - total number of sample, N.S. - Not significant, $\mathrm{p}$ - Statistical significance, * - institutions with digital waiting line without public consultation by the user, $\mathrm{X}^{2}$ - chi-square test

Source: Total data from Ophthalmology public services - National Character - researched on the Internet during June / July 2015. 
Universities and hospitals are older in organization, and due to their multidisciplinary nature, they have greater difficulty in the global installation of an electronic medical record of multiple features. Besides the need to meet different specialties, there is the problem of contemplating a whole extensive previous medical file on paper which needs to be updated. However, many of these institutions have partial filing systems as for surgical procedures and specific complementary exams.

A common feature to all institutions studied is the presence of medical residency in Ophthalmology. Many of them are accredited to Conselho Brasileiro de Oftalmologia, or associated to Sociedade Brasileira de Oftalmologia or just COREM (Co- missão Nacional de Residência Médica - Ministério da Educação - MEC).

As shown in table 2 the frequency of having a complete digital package is still very small and restricted to universities. Table 2 shows the advantage of developing the software at the university. Their utilization and practicality features are highlighted. This type of data is highlighted as significant in the statistical test (Table 2).

Similarly, you can see that the few unidisciplinary Ophthalmology institutions as the eyes banks, and few having digital surgical waiting list, have software developed by private companies.

Table 2

\section{Correlation between institutions, implementation of digital package and source of digital software: total data from public services in Ophthalmology}

\begin{tabular}{|c|c|c|c|c|c|c|c|c|}
\hline \multirow[t]{2}{*}{ Presence of digital page } & \multirow[t]{2}{*}{$\mathbf{N}$} & \multicolumn{3}{|c|}{ Digital Package } & \multicolumn{3}{|c|}{ Origem do software } & \multirow{2}{*}{$\begin{array}{c}\text { p Value } \\
\text { Teste } X^{2}-\text { Fisher }\end{array}$} \\
\hline & & Complete & Partial & Absent & $\begin{array}{l}\text { Development } \\
\text { of own public }\end{array}$ & $\begin{array}{l}\text { Private } \\
\text { company }\end{array}$ & Absent & \\
\hline $\begin{array}{l}\text { Multidisciplinary assistance } \\
\text { institutions }\end{array}$ & 15 & - & 10 & 05 & - & 10 & 05 & N.S. \\
\hline $\begin{array}{l}\text { Unidisciplinary assistance } \\
\text { institutions }\end{array}$ & 03 & - & 02 & 01 & - & 02 & 01 & N.S. \\
\hline Eye Bank & 06 & 02 & 04 & - & - & 06 & - & N.S. \\
\hline
\end{tabular}

$\mathrm{n}$ - total number of sample, N.S. - Not significant, p - Statistical significance, ${ }^{*}$ - institutions with digital waiting line without public consultation by the user, $\mathrm{X}^{2}$ - chi-square test

Source: Total data from Ophthalmology public services - National Character - researched on the Internet during June / July 2015.

\section{DisCUSSION}

Institutions with simpler organizations such as the unidisciplinary entities of ophthalmology only could be the easier element to obtain the full digital package. The electronic medical record without the problem of multidisciplinary and similarly applied to the digital waiting list would be these elements. However, due to the lower number of these entities, as well as a minor importance in technical participation and management, make them present lower participation in this type of digital proposal.

However, it is noteworthy that the eye bank institutions are a more complete concept of digital package. They even include public consultation by the user of surgical digital waiting line, which in the ophthalmology specialty was the only institution allocated to the research for this concept. ${ }^{13,14}$

However, the public consultation on the Internet related to the waiting list for elective surgical procedures not related to organ transplant was not present in any other institution of the specialty. Only one institution linked to orthopedic specialty contributes to this other concept. ${ }^{13,14}$

Even in the literature of administrative medical management, there are few national references on the subject of digital surgical waiting list. The advantages of a digital surgical waiting line with encryption features are evident, even in the absence of external public consultation. The digital surgical waiting line can an aid of administrative or technical character, or even for legal consultation. 1,2,15,16

According to the proposal of a technical manual aimed at handling digital hospital management, it is necessary to attach the personal hospital records of the patients to one register integrated to SUS or Serviços de Regulação de Atendimentos, as well as to a previous register within the management network of the institution. $1,2,5$

As suggestions of programmatic software criteria there could be an Input and Output of data with special multidisciplinary aspects. That is, there would be an entry for the "status" where these aspects would not be the same for each specialty in particular, and there could be more than one waiting line according to each morbidity or aspect associated to the difficulties of the surgery (surgical complexity, more sophisticated equipment, type of anesthesia, need for ICU support). ${ }^{17,18}$

Another device would be priority according to aspects of worsening the condition of morbidity where the need of the procedure could be changed after trial by the manager of the waiting line. This type of device must have its reasons explained and recorded with the accompanying comments attached to the registration of each patient. ${ }^{1,2,5}$ 
Due to elective surgical procedures, the digital waiting list can be periodically reviewed by the manager looking for dropouts, deaths and procedures carried out at other institutions. Just as changing priorities, the reasons for the waiting list updates should be provided and recorded, and the comments allocated along with the registration of each patient. ${ }^{4,5}$

The surgical line of the eye bank is more immutable. This is governed by federal law for organ transplants. Such a situation, however, makes up the need for further public consultation to know the situation of each patient regarding the surgical waiting line. The digital option is even more imperative under this circumstance. ${ }^{3,4,6}$

\section{CONCLUSION}

There is still a long way for the public health system to present a competent digital system for service, and mainly a faster and more transparent surgical waiting list to its users. There is need for a technical and administrative team better prepared and trained for the help of medical professionals. However, this is another one barrier to overcome regarding the lack of equipment and supplies to meet more effectively the demand of users.

\section{RefERENCES}

1. Gabriel RA, Skowron M, Carrubba D, Hepner DL, Bader Impact of information technology on preoperative scheduling systems: a pilot study modeling scheduling systems in the preoperative clinic. Am J Med Pract Manage. 2015;30(6 Spec):2-7.

2. Ballini L, Negro A, Maltoni S, Vignatelli L, Flodgren G, Simera I, Holmes J, Grilli R. Interventions to reduce waiting times for elective procedures. The Cochrane Library; 2015. [Published online on 2015, Feb 23]. DOI: 10.1002/14651858.CD005610.pub2

3. Transplantes de Órgãos no Brasil. Rev Assoc Med. Bras. 2003; 49( 1):1.

4. Brasil. Ministério da Saúde, Secretaria de Atenção à Saúde. Portaria No 741, de 19 de Dezembro de 2005. Referente a gestão de atendimento de oncologia em instituições públicas. Disponível em: http://portal.anvisa.gov.br/wps/wcm/connect/3092aa80474 594909c3fdc3fbc4c6735/PORTARIA+ ${ }^{\circ}+741-2005 . p d f$

5. São Paulo. Secretaria Municipal de Saúde. Projeto de informatização [Internet]. [citado 2015 Dec 12]. Disponível em: www. saude.sp.gov/sms.atti em julho/2015.

6. Almeida Sobrinho EF,Negrão BC, Almeida HG. Perfil epidemiológico de pacientes na fila de transplante penetrante de córnea no estado do Pará, Brasil. Rev Bras Oftalmol. 2011;70(6):384-90.
7. Sarmento Junior KM, Tomita S; Avila Kos AO. O problema da fila de espera para cirurgias otorrinolaringológica. Rev Bras Otolar-rinolaringol. 2005;71(3):265-62.

8. Projeto UNA/SUS. Plataforma Arouca [Internet]. Instituições de atendimento de oftalmologia no Brasil. [citado 2015 Jun 1]. Disponível em: www.unasus.gov.br/plataforma Arouca.

9. Conselho Brasileiro de Oftalmologia. Instituiçõesc para residência médica em Oftalmologia [Internet]. [citado 2015 Jun 1]. Disponível em: www.cbo.com.br/instituições

10. Banco de olhos de Sorocaba. [Internet]. [citado 2015 Dez 22]. Disponível em: www.hosbos.com.br.

11- EBESERH - Hospitais universitários e gerência administrativa [Internet]. [citado 2015 Dez 22]. Disponível em: www.ebserh. gov.br.

12. Consulta com tema: Banco de Olhos, Disponível em www.into. saude.gov.brlbanco de olhos, em 22/12/2015.

13. Fila cirúrgica zero [Internet]. [citado 2015 Dez 22]. Disponível em: www.bancodeolhos de cascavel.com.brlfila zero.

14. Fila cirúrgica e banco de olhos [Internet]. [citado 2015 Dez 22]. Disponível em: http://www.lionsclubs.org/PO/our-work/sight-programs/sight-services/eye-banks.php

15. Brasil. Ministério da Saude Portaria $n^{\circ}$ 957, de 15 de Maio de 2008. Dispõe sobre Regulação de Rede Pública de Saúde de Oftalmologia. Brasil: Ministério da Saude; 2008. [citado 2016 Mar 10]. Disponível em: www.saude.gov.br.

16. Collazos K, Gotardo RT, Barreto JM. Metodologia para construção do prontuário médico eletrônico. In: XVIII Congresso Brasileiro de Engenharia Biomédica. São José dos Campos, SP; 2002. [citado 2003 Jul 10]. Disponível em: http://www.sbis-rj.org/info rmedica/ ebm/cbeb20 8.pdf.

17. Silva FB, Tavares-Neto J. Avaliação dos prontuários médicos de hospitais de ensino do Brasil. Rev Bras Educ Med. 2007;31(2):113-26.

18. Sociedade Brasileira de Informática em Saúde. Manual de Certificac'ão para Sistemas de Registro Eletronico em Sauìde (S-RES) Versão 4.1. Sociedade Brasileira de Informática em Saúde; 2013. [Marcelo Lucio da Silva, editor]. [citado 2016 Mar 10]. Disponível em: www.sbis.org.br

\section{Corresponding author:}

UFF - Universidade Federal Fluminense

Rua Marques do Paraná 305, Centro, Niterói - RJ. 24033-900.

E-mail: e_damasceno@yahoo.com 